GRASAS Y ACEITES 69 (2)

April-June 2018, e250

ISSN-L: 0017-3495

https://doi.org/10.3989/gya.1220172

\title{
Modeling of volatile and phenolic compounds and optimization of the process conditions for obtaining balanced extra virgin olive oils
}

\author{
A.M. Vidal ${ }^{\mathrm{a}}$, S. Alcalá ${ }^{\mathrm{a}}$, M.T. Ocaña ${ }^{\mathrm{b}}$, A. De Torres ${ }^{\mathrm{a}}$, F. Espínola ${ }^{\mathrm{a}}$ and M. Moya ${ }^{\mathrm{a}, \bigotimes}$ \\ ${ }^{\mathrm{a}}$ Center for Advanced Studies in Energy and Environment (CEAEMA). Agrifood Campus of International Excellence (ceiA3). \\ Department of Chemical, Environmental and Materials Engineering. University of Jaén, 23071 Jaén, Spain. \\ ${ }^{b}$ Department of Didactic of Sciences. University of Jaén, 23071 Jaén, Spain. \\ ${ }^{\square}$ Corresponding author: mmoya@ujaen.es
}

Submitted: 05 December 2017; Accepted: 12 February 2018

\begin{abstract}
SUMMARY: The main objective of this paper is to obtain extra virgin olive oils (EVOOs) which are balanced in volatile and phenolic compounds. An experimental design was performed and response surface methodology was applied. The factors for malaxation were: temperature $20-40{ }^{\circ} \mathrm{C}$, time $30-90 \mathrm{~min}$, and hole diameter of hammer-crusher 4.5-6.5 mm. The results show that high temperatures and small hole diameter must be used in order to obtain a higher content in phenolic compounds, while for volatile compounds a low temperature and large hole diameter must be used. The models predict that the best and more balanced EVOO are obtained with the hole diameter of greater size and a medium-low temperature. Thus, for a hammer-crusher hole diameter of $6.5 \mathrm{~mm} 337$ and $356 \mathrm{mg} / \mathrm{kg}$ total HPLC phenols were obtained for malaxation temperature of 20 and $25^{\circ} \mathrm{C}$, respectively and, likewise, 12.7 and $11.5 \mathrm{mg} / \mathrm{kg}$ total LOX volatiles.
\end{abstract}

KEYWORDS: Balanced olive oils; Oil mill; Phenolic compounds; Response Surface Methodology; Volatile compounds

RESUMEN: Modelado de compuestos volátiles y fenólicos y optimización de las condiciones de operación para obtener aceites de oliva virgen extra equilibrados. El principal objetivo es obtener aceites de oliva vírgenes extra (AOVEs) equilibrados en compuestos volátiles y fenólicos. Se ha realizado un diseño experimental y aplicado metodología de superficie de respuesta. El rango de los factores de batido fue, temperatura $20-40{ }^{\circ} \mathrm{C}$ y tiempo 30-90 min, y diámetro de orificio del molino de martillos 4,5-6,5 mm. Los resultados muestran que a altas temperaturas y pequeño diámetro de orificio se obtienen elevados contenidos en compuestos fenólicos, mientras que para volátiles se debe usar temperatura baja y orificio de gran diámetro. Los modelos predicen que el mejor y más equilibrado EVOO se obtiene con el orificio de mayor tamaño y temperatura media-baja. Así, para diámetro de orificio de $6,5 \mathrm{~mm}$ se obtienen 337 y $356 \mathrm{mg} / \mathrm{kg}$ de fenoles totales HPLC, para temperaturas de batido de 20 y $25^{\circ} \mathrm{C}$ respectivamente y, asimismo, 12,7 y $11,5 \mathrm{mg} / \mathrm{kg}$ de volátiles totales LOX.

PALABRAS CLAVE: Aceites de oliva equilibrados; Almazara; Compuestos fenólicos; Compuestos volátiles; Metodología de superficie de respuesta

ORCID ID: Vidal AM https://orcid.org/0000-0003-3803-1876, Alcalá S https://orcid.org/0000-0002-5172-0847, Ocaña MT https://orcid.org/0000-0001-6944-8178, De Torres A https://orcid.org/0000-0002-4613-0279, Espínola F https:// orcid.org/0000-0002-9570-6297, Moya M https://orcid.org/0000-0002-9820-396X

Citation/Cómo citar este artículo: Vidal AM, Alcalá S, Ocaña MT, De Torres A, Espínola F, Moya M. 2018. Modeling of volatile and phenolic compounds and optimization of the process conditions for obtaining balanced extra virgin olive oils. Grasas Aceites 69 (2), e250. https://doi.org/10.3989/gya.1220172

Copyright: (C2018 CSIC. This is an open-access article distributed under the terms of the Creative Commons Attribution 4.0 International (CC BY 4.0) License. 


\section{INTRODUCTION}

Volatile and phenolic compounds are different groups of compounds present in virgin olive oil (VOO). Most of the taste and aroma of olive oil depend on these compounds. The volatile compounds present in olive oil are related to sensory attributes, and play an important role in consumers' sensory perceptions. These compounds are originated during the olive oil production process, most of them through the actions of enzymes which are released during the olive milling process. Many pathways are involved in the production of volatile compounds. Unsaturated fatty acids, such as linolenic and linoleic acid, are transformed into compounds of five and six carbon atoms through the Lipoxygenase (LOX) pathway (Gómez-Rico et al., 2006; Sanchez and Salas, 2003). These compounds contribute to the pleasant aromas of olive oil (Angerosa et al., 2000).

Sensory characteristics are a key factor in the perception of a product's quality level on the part of consumers. Volatile compounds are mainly responsible for aroma, even though phenolic compounds are related to the sense of the taste of olive oil (Angerosa et al., 2004). Several factors influence the composition of volatile compounds of olive oil, from the agronomic and climatic to the technological ones (Luna et al., 2006). However, the activity of the enzymes involved in the LOX pathway is genetically determined (Clodoveo et al., 2014).

On the other hand, the phenolic compounds of olive oil are a complex group of chemical compounds which contribute to the stability of olive oil (Franco et al., 2014). The composition of these compounds is mainly determined by the elaboration process, production technology, the variety and maturation of olives and the agro-climatic parameters (Romero et al., 2016; Servili et al., 2004). An overripe harvest of olives involves a decrease in the concentration of phenolic compounds. Therefore, olives should be harvested at the early stage of ripeness to obtain the maximum amount of phenolic compounds.

The antioxidant capacity, the increase in the quantity of HDL and the decrease in the quantity of LDL, the inhibition of the proliferation of cancer cells, the prevention of many diseases and the decrease in oxidative stress are just some of the properties of these compounds (Tripoli et al., 2005). Several research papers (Beauchamp et al., 2005; Cicerale et al., 2012) have stated that oleocanthal has anti-inflammatory properties similar to classic nonsteroidal anti-inflammatory drugs (NSAID) such as Ibuprofen, suppressing the Cyclooxygenase enzyme $(\mathrm{COX})$ involved in the prostaglandin synthesis pathway. Recently, oleocanthal has been unveiled as a powerful therapeutic molecule for several diseases.
It can show pharmacological properties for various pathogenic processes, including inflammation, cancer and neurodegenerative diseases (Scotece et al., 2015).

The hole diameter of the hammer-crusher and temperature and time in the malaxation stage are the main technological factors which influence the EVOO production process. These parameters can be modified to obtain olive oils of excellent quality. On the basis of the above, the main aim of this research is to determine the best conditions to obtain healthy and high quality EVOO, with a large quantity of phenolic compounds and a good profile of volatile compounds (balanced EVOO).

\section{MATERIALS AND METHODS}

\subsection{Olives}

Olive fruits, Olea europaea L., were hand-picked from a traditional grove in Sierra Mágina (Jaén, Spain). The cultivated variety is Picual with a 4.9 maturity index, determined according to Uceda and Frias and described by Espínola et al. (2009); $486 \mathrm{~g} / \mathrm{kg}$ moisture content, determined by drying milled paste at $105{ }^{\circ} \mathrm{C}$, and a $284 \mathrm{~g} / \mathrm{kg}$ oil content, determined by the Soxhlet method. The olives were collected from unirrigated land.

\subsection{Olive oil extraction}

Oils were obtained under laboratory-scale conditions using an Abencor centrifugal system (Abencor analyzer, MC2, Ingeniería y Sistemas S.L., Seville, Spain) (Espínola et al., 2011). The oils obtained were decanted into a graduated test tube for at least three hours, paper filtered and stored in amber glass bottles, under $\mathrm{N}_{2}$ atmosphere, at $-18{ }^{\circ} \mathrm{C}$ until they were analyzed.

\subsection{Analysis of phenolic compounds}

The method proposed by the International Olive Council (COI/T.20/Doc No 29) was used to determine the phenolic compounds present in virgin olive oils via High Performance Liquid Chromatography (HPLC). The equipment used was a liquid chromatograph (Shimadzu Corp., Kyoto, Japan) with the essential components: an elution pump (model LC-20AD), solvent degasser (model DGU-20A5), a refrigerated automatic injector (model SIL20ACHT), a column oven (model CTO-10AsvpC), a diode array detector (model SPD-M20) and LC LabSolutions V.5.42.SP3 software (Shimadzu Corp., Kyoto, Japan). The column used was BDS Hypersil C18 (Thermo Scientific, USA), the particle size was $5 \mu \mathrm{m}$, the column size was $25 \mathrm{~cm}$ and the internal diameter was $4.6 \mathrm{~mm}$. The mobile phase was a 
ternary gradient made up by orthophosphoric acidwater to $0.2 \%$ (A), Methanol (B) and Acetonitrile (C). The proportions of the phases are changed over time by means of a flow ramp. The initial proportion of phase A was $96 \%, \mathrm{~B}$ and $\mathrm{C}$ were $2 \%$. At minute 40 , the proportion of phase A was $50 \%$, B and $\mathrm{C}$ were $25 \%$. At minute 45 , the proportion of phase $\mathrm{A}$ was $40 \%, \mathrm{~B}$ and $\mathrm{C}$ were $30 \%$. At minute 60 , the proportion of phase $\mathrm{A}$ was $0 \%, \mathrm{~B}$ and $\mathrm{C}$ were $50 \%$. From minute 72 to 80 the proportions of the phases were identical to the initial ones; minute 80 was the end of the chromatogram. The elution flow was $1 \mathrm{~mL} / \mathrm{min}$. The oven temperature was set at $30^{\circ} \mathrm{C}$ and the injected volume of sample was $20 \mu \mathrm{L}$. The detector UV provided a signal at $280 \mathrm{~nm}$. The phenolic compounds were quantified through the addition of syringic acid as internal standard and tyrosol as external standard. The results obtained were expressed as $\mathrm{mg}$ of tyrosol per $\mathrm{kg}$ of oil. The phenolic compounds were identified through comparison with the following analytical standards: Syringic acid, vanillin, luteolin, vanillic acid, oleuropein, trans-ferulic acid and trans-cinamic acid, all purchased from Fluka (Milan, Italy). Tyrosol, pinoresinol, caffeic acid, apigenin and p-coumaric acid were purchased from Sigma-Aldrich (St. Louis, MO, USA). $o$-coumaric acid and hydroxytyrosol were purchased from Extrasynthese (Genay Cedex, France). 3,4-DHPEA-EDA (oleacein) and p-HPEA-EDA (oleocanthal) were identified by analytical standards supplied by the Department of Organic Chemistry from the University of Jaén. p-HPEA-EA and 3,4-DHPEA-EA were identified using the method proposed by COI, Determination of bio-phenols in olive oils by HPLC, (COI/T.20/ Doc No 29).

The Folin-Ciocalteau reagent was used to determine the total quantity of phenolic compounds in the olive oil, with slight adjustments (VázquezRoncero et al., 1973). The weight of the oil samples was $1 \mathrm{~g}$. The sample was placed in a tube and dissolved in $5 \mathrm{~mL}$ of hexane. The liquid-liquid extraction was performed by repeating contact with a $2 \mathrm{~mL}$ methanol-water solution (60:40). This extraction was repeated three times. Each contact was shaken for 2 min with a Vortex type agitator. The methanolic extracts were collected in a test tube of $10 \mathrm{~mL}$. To conclude, the methanol-water solution was added to complete $10 \mathrm{~mL}$. The methanolic extracts were reacted with the Folin-Ciacolteau reagent. The absorbance of the solutions was measured at a wavelength of $725 \mathrm{~nm}$. The equipment used was a UV spectrophotometer, model Shimadzu UV-Spectrophotometer 1800 (Kyoto, Japan). A standard curve was used to determine the quantity of phenolic compounds, using caffeic acid as external standard. The results were expressed as $\mathrm{mg}$ of caffeic acid per $\mathrm{kg}$ of olive oil.
The antioxidant potential was determined as DPPH free radical scavenging activity. A DPPH stock solution $(0.1 \mathrm{mmol} / \mathrm{L})$ was prepared in methanol, and further diluted to $1.0 \mathrm{AU}$ at $515 \mathrm{~nm}$ prior to use. Aliquots of extract $(20-2000 \mathrm{~mL})$ were adequately diluted to a volume of $200 \mathrm{~mL}$ and added to $1.5 \mathrm{~mL}$ of DPPH solution cuvettes, shaken and kept in the dark for $60 \mathrm{~min}$, and then the absorbance was measured at $515 \mathrm{~nm}$ using methanol as a blank. The percentage of scavenged DPPH radicals was calculated according to Equation 1:

$$
\% D P P H_{\text {rem }}=\frac{A_{0}-A_{\text {sample }}}{A_{0}} \times 100
$$

where $A_{0}$ and $A_{\text {sample }}$ stand for the absorbance of the control and sample, respectively. The percentage of inhibition was converted into antioxidant activity by using Trolox as standard antioxidant.

\subsection{Analysis of volatile compounds}

Headspace solid-phase micro extraction (HS-SPME) and the gas chromatography-flame ionization detector (GC-FID) technique were used for the analysis of volatile compounds.

Two sample grams were placed in a $20 \mathrm{~mL}$ amber glass vial tightly capped with polytetrafluoroethylene (PTFE)/silicone septum and a magnetic cap. The vial was heated up to $40{ }^{\circ} \mathrm{C}$ for 10 minutes to reach the equilibration of volatile compounds in the headspace. Afterwards, the SPME needle was inserted through the septum and the fiber was exposed for $40 \mathrm{~min}$. The SPME fiber $(2 \mathrm{~cm}$ length and 50/30 $\mu \mathrm{m}$ film thickness), purchased from Supelco (Bellefonte, PA, USA), was composed of Carboxen/DVB/ polydimethylsiloxane (PDMS). Previously, the fiber had been conditioned following the instructions of the supplier.

The GC-FID analysis was performed using a gas chromatograph model 7890B (Agilent Technologies, Santa Clara, CA, USA). The gas chromatograph was equipped with a split/splitless injector and a flame ionization detector. The volatile compounds adsorbed in the fiber were desorbed into the injector port for $1 \mathrm{~min}$ in splitless mode. The DB-WAXetr polyethylene glycol capillary column (30 m length, $0.25 \mathrm{~mm}$ internal diameter, $0.25 \mu \mathrm{m}$ coating) (Agilent Technologies, USA) was used for the chromatographic separation. The carrier gas was helium at a flow rate of $1 \mathrm{~mL} / \mathrm{min}$. The injector temperature was $260^{\circ} \mathrm{C}$ and the detector temperature was $280^{\circ} \mathrm{C}$. The oven temperature was initially $40^{\circ} \mathrm{C}$ for $10 \mathrm{~min}$. Afterwards, the temperature was increased with a ramp of $3{ }^{\circ} \mathrm{C} / \mathrm{min}$ up to $160{ }^{\circ} \mathrm{C}$ and immediately increased with a ramp of $15^{\circ} \mathrm{C} / \mathrm{min}$ up to $200{ }^{\circ} \mathrm{C}$ and held for $5 \mathrm{~min}$ to the end. The integrations were 
performed with Agilent OpenLAB ChemStation C.01.06 Software (Agilent Technologies, CA, USA).

The chromatographic peaks were quantified by the Internal Standard Method. 4-Methyl-2-pentanol was the internal standard and each and every one of the compounds was used as external standard. The results obtained were expressed as mg of each standard compound per kg of oil.

For the analysis of volatile compounds, 39 analytical standards were used: acetic acid, trans2-pentenal, 1-penten-3-one, pentanal, 1-penten3-ol, pentan-1-ol, 2-methyl-1-butanol, hexanal, cis-3-hexen-1-ol, hexan-1-ol, heptanal, octane, octanal, 1-octen-3-ol, cis-3-hexenyl acetate, hexyl acetate, trans, trans-2,4-decadienal, propionic acid, 2-methylpropan-1-ol and butanoic acid, all supplied by Fluka (Buchs, Switzerland); 4-methylpentan2-ol, trans, trans-2,4-heptadienal, trans-2-heptenal, heptan-2-ol, trans-2-penten-1-ol, 2-methylbutanal, 3-methylbutanal, 3-methyl butanoic acid, ethyl acetate, cis-3-hexenal, 2-methylpropanoic acid, ethyl butanoate, trans,trans-2,6-nonadienal, and trans2-hexenyl acetate were supplied by Sigma-Aldrich (St. Louis, MO, USA); pentan-3-one and nonanal were supplied by Supelco (Bellefonte, PN, USA); cis2-penten-1-ol and trans-2-hexen-1-ol were supplied by SAFC; trans-2-hexenal was supplied by Acrös Organics (Geel, Belgium).

\subsection{Experimental design and statistical analysis}

The Statistical Design of Experiments (SDE) and Response Surface Methodology (RSM) were used to plan and analyze the experiments. Both constitute a planning methodology and analysis based on statistical tools, where SDE selects the optimal experimental strategy to obtain the desired information with the minimum cost of analysis and RSM evaluates the experimental results ensuring maximum reliability in the conclusions (Box et al., 2005).

In this process, a Box-Behnken design, with five repetitions of central points, for three factors was used: diameter of the holes of the hammer-crusher, temperature and malaxation time. The range of variation of these factors is 4.5 to $6.5 \mathrm{~mm}, 20$ to $40^{\circ} \mathrm{C}$ and 30 to 90 minutes, respectively. Table 1 shows the different trials proposed by the design and their order of execution. Likewise, Table 1 also shows the actual and coded values of the factors used in each trial. The design tests allow to determine the influence of these technological factors on the phenolic and volatile compounds obtained in the olive oils.

TABLE 1. Experimental design and responses for Picual virgin olive oil

\begin{tabular}{|c|c|c|c|c|c|c|c|}
\hline \multirow[b]{2}{*}{$\begin{array}{l}\text { Design } \\
\text { points* }\end{array}$} & \multicolumn{3}{|c|}{ Actual factors (coded factors) } & \multicolumn{4}{|c|}{ Responses*** } \\
\hline & $\begin{array}{l}\text { Diameter** } \\
(\mathbf{m m})\end{array}$ & $\begin{array}{c}\text { Temperature } \\
\left({ }^{\circ} \mathbf{C}\right)\end{array}$ & $\begin{array}{l}\text { Time } \\
(\mathrm{min})\end{array}$ & $\begin{array}{c}\text { Total HPLC } \\
\text { phenols } \\
\text { (mg/kg tyrosol) }\end{array}$ & $\begin{array}{c}\text { Total Folin } \\
\text { phenols } \\
\text { (mg/kg caffeic } \\
\text { acid) }\end{array}$ & $\underset{(\mu \mathrm{mol} / \mathrm{kg})}{\text { DPPH }}$ & $\begin{array}{c}\text { Total LOX } \\
\text { volatiles } \\
\text { (mg/kg) }\end{array}$ \\
\hline 1 & $5.5(0)$ & $30(0)$ & $60(0)$ & 411 & 415 & 1109 & 12.2 \\
\hline 2 & $5.5(0)$ & $20(-1)$ & $90(+1)$ & 357 & 344 & 844 & 12.4 \\
\hline 3 & $4.5(-1)$ & $30(0)$ & $90(+1)$ & 508 & 467 & 1306 & 12.4 \\
\hline 4 & $6.5(+1)$ & $30(0)$ & $90(+1)$ & 474 & 462 & 1393 & 11.7 \\
\hline 5 & $6.5(+1)$ & $40(+1)$ & $60(0)$ & 747 & 761 & 2298 & 7.21 \\
\hline 6 & $5.5(0)$ & $20(-1)$ & $30(-1)$ & 351 & 404 & 979 & 11.2 \\
\hline 7 & $6.5(+1)$ & $20(-1)$ & $60(0)$ & 356 & 374 & 910 & 13.4 \\
\hline 8 & $5.5(0)$ & $40(+1)$ & $90(+1)$ & 851 & 866 & 2668 & 7.03 \\
\hline 9 & $4.5(-1)$ & $40(+1)$ & $60(0)$ & 758 & 762 & 2581 & 7.45 \\
\hline 10 & $5.5(0)$ & $40(+1)$ & $30(-1)$ & 760 & 862 & 2662 & 7.40 \\
\hline 11 & $6.5(+1)$ & $30(0)$ & $30(-1)$ & 380 & 422 & 1229 & 10.1 \\
\hline 12 & $4.5(-1)$ & $30(0)$ & $30(-1)$ & 544 & 642 & 1919 & 9.21 \\
\hline 13 & $5.5(0)$ & $30(0)$ & $60(0)$ & 610 & 724 & 1873 & 8.03 \\
\hline 14 & $4.5(-1)$ & $20(-1)$ & $60(0)$ & 423 & 444 & 1427 & 10.9 \\
\hline 15 & $5.5(0)$ & $30(0)$ & $60(0)$ & 583 & 639 & 1601 & 8.31 \\
\hline 16 & $5.5(0)$ & $30(0)$ & $60(0)$ & 522 & 556 & 1636 & 8.60 \\
\hline 17 & $5.5(0)$ & $30(0)$ & $60(0)$ & 415 & 483 & 1298 & 10.1 \\
\hline
\end{tabular}

* Experiments were run in a random order ** Hole diameter of the hammer-crusher $* * *$ Average of two replicates 
The factors were coded according to the following transformation, Equation 2.

$$
x_{i}=\frac{X_{i}-X_{0}}{\Delta X}
$$

Where $x_{i}$ is the dimensionless coded value of the factor $X_{i}, X_{0}$ is the value of $X_{i}$ at the center point or average level of the factor and $\Delta \mathrm{X}$ the half-step change. The factors are usually coded because they provide a uniform framework to investigate the effects of factors and the coefficients of the models can be easily compared.

The experimental results were analyzed by Design-Expert v. 8.0.7.1 software (Stat-Ease, Inc., Minneapolis, MN, USA). The adequacy of the proposed model was determined by evaluating the lack of fit, coefficient of determination $\left(\mathrm{R}^{2}\right)$ and the Fisher value (F-value) obtained from the analysis of variance (ANOVA). A quadratic model for each response studied was used according to Eq. 3:

$$
\begin{aligned}
Y= & \beta_{0}+\beta_{1} D+\beta_{2} T+\beta_{3} t+ \\
& \beta_{12} D T+\beta_{13} D t+\beta_{23} T t+ \\
& \beta_{11} D^{2}+\beta_{22} T^{2}+\beta_{33} t^{2} \pm S D
\end{aligned}
$$

Where: $\mathrm{D}$ is the hole diameter of the crusher $(\mathrm{mm}), \mathrm{T}$ is the malaxation temperature $\left({ }^{\circ} \mathrm{C}\right)$ and $\mathrm{t}$ is the malaxation time ( $\mathrm{min})$. The predicted response (Y) was correlated with the set of coefficients $(\beta)$ : the intercept $\left(\beta_{0}\right)$, linear $\left(\beta_{1}, \beta_{2}, \beta_{3}\right)$, interaction $\left(\beta_{12}\right.$, $\left.\beta_{13}, \beta_{23}\right)$ and quadratic $\left(\beta_{11}, \beta_{22}, \beta_{33}\right)$. SD is the standard deviation of the model.
The statistical significance of the model and model coefficients were determined at 5\% probability level $(p$-value $=0.05)$. The models for each response were expressed in terms of actual factors and without taking into account terms which were not statistically significant.

\section{RESULTS AND DISCUSSION}

\subsection{Effect of technological factors on phenolic compounds and antioxidant activity}

Phenolic compounds play a very important role in $\mathrm{VOO}$ due to their high antioxidant activity, which contributes to the shelf life of the oils and, in addition, gives them their typical bitter taste (Zribi et al., 2013).

Table 1 shows the total phenols as determined by HPLC $(\mathrm{mg} / \mathrm{kg}$ tyrosol), which are the sum of the individual phenolic compounds, total phenols determined by Folin-Ciocalteau reagent $(\mathrm{mg} / \mathrm{kg}$ caffeic acid) and the antioxidant potential determined by DPPH free radical scavenging activity $(\mu \mathrm{mol} / \mathrm{kg}$ ). Table 2 shows the content of individual phenolic compounds identified by HPLC $(\mathrm{mg} / \mathrm{kg}$ tyrosol). Table 3 shows the models obtained for all the responses, which can be used later to predict the answers once the factors have been fixed. All the responses in Tables 1, 2 and 4 were determined in duplicate; the average values are shown in these tables as well. The software generates the regression equations after discarding the terms which are not statistically significant ( $p$-value $>0.05$ ); however, in order to support hierarchy, some linear terms were

TABLE 2. Responses for individual phenolic compounds by HPLC* (mg/kg tyrosol)

\begin{tabular}{lccccccccccccccccccc}
\hline Design points & $\mathbf{1}$ & $\mathbf{2}$ & $\mathbf{3}$ & $\mathbf{4}$ & $\mathbf{5}$ & $\mathbf{6}$ & $\mathbf{7}$ & $\mathbf{8}$ & $\mathbf{9}$ & $\mathbf{1 0}$ & $\mathbf{1 1}$ & $\mathbf{1 2}$ & $\mathbf{1 3}$ & $\mathbf{1 4}$ & $\mathbf{1 5}$ & $\mathbf{1 6}$ & $\mathbf{1 7}$ \\
\hline hydroxytyrosol & 8.40 & 4.61 & 4.07 & 5.68 & 4.35 & 4.09 & 4.81 & 4.27 & 1.72 & 4.12 & 3.95 & 5.60 & 4.11 & 4.02 & 1.76 & 2.38 & 1.71 \\
tyrosol & 1.46 & 1.25 & 1.80 & 3.35 & 1.53 & 0.88 & 1.77 & 1.57 & 1.46 & 1.23 & 1.38 & 1.53 & 1.23 & 1.26 & 3.72 & 2.65 & 1.84 \\
vainillin & 0.89 & 1.73 & 1.46 & 1.29 & 1.86 & 1.23 & 0.63 & 2.91 & 2.38 & 1.71 & 1.54 & 1.01 & 1.45 & 1.01 & 1.55 & 1.89 & 1.97 \\
p-coumaric acid & 6.10 & 2.61 & 2.79 & 3.66 & 5.00 & 1.51 & 2.43 & 2.45 & 2.54 & 1.58 & 1.39 & 1.33 & 1.39 & 2.20 & 2.06 & 2.32 & 1.74 \\
trans-ferulic acid & 4.88 & 2.28 & 6.92 & 8.10 & 8.63 & 2.25 & 1.60 & 11.5 & 10.2 & 6.80 & 4.93 & 2.52 & 5.39 & 2.50 & 3.74 & 5.28 & 6.38 \\
3.4-DHPEA-EDA & 150 & 107 & 188 & 190 & 285 & 140 & 122 & 338 & 320 & 356 & 159 & 252 & 298 & 164 & 252 & 218 & 164 \\
(oleacein) & & & & & & & & & & & & & & & & & & & \\
3.4-DHPEA-EA & 64.6 & 51.3 & 78.4 & 83.0 & 192 & 44.1 & 58.0 & 233 & 179 & 157 & 52.9 & 87.5 & 111 & 62.4 & 115 & 104 & 75.9 \\
p-HPEA-EDA & 45.2 & 36.7 & 63.2 & 45.7 & 78.1 & 25.8 & 28.1 & 90.8 & 77.4 & 62.2 & 41.3 & 39.6 & 55.6 & 38.8 & 53.6 & 53.0 & 50.5 \\
(oleocanthal) & & & & & & & & & & & & & & \\
p-HPEA-EA & 36.3 & 46.3 & 50.3 & 49.1 & 65.4 & 35.9 & 41.0 & 72.1 & 61.7 & 48.2 & 43.4 & 28.8 & 32.9 & 33.0 & 41.3 & 40.1 & 45.5 \\
pinoresinol & 6.23 & 6.07 & 5.47 & 4.86 & 10.9 & 9.35 & 7.92 & 8.45 & 11.4 & 37.0 & 14.6 & 44.1 & 32.5 & 29.2 & 34.0 & 11.8 & 7.48 \\
luteolin & 2.52 & 2.16 & 6.23 & 3.04 & 4.58 & 2.00 & 2.50 & 3.63 & 4.51 & 4.39 & 1.73 & 2.65 & 2.31 & 4.63 & 4.21 & 6.81 & 4.62 \\
apigenin & 3.24 & 2.83 & 4.77 & 3.31 & 3.44 & 2.59 & 3.32 & 4.74 & 5.61 & 8.17 & 1.93 & 3.77 & 3.69 & 2.96 & 2.98 & 2.70 & 2.26 \\
\hline
\end{tabular}

3,4-DHPEA-EDA: dialdehyde form of decarboxymethyl oleuropein aglycone

p-HPEA-EDA: dialdehyde form of decarboxymethyl ligstroside aglycone

3,4-DHPEA-EA: aldehyde and hydroxylic form of oleuropein aglycone

p-HPEA-EA: aldehyde and hydroxylic form of ligstroside aglycone

* Average of two replicates 
6• A.M. Vidal, S. Alcalá, M.T. Ocaña, A. De Torres, F. Espínola and M. Moya

TABLE 3. Models (Eq. 3) in terms of actual factors and statistical parameters for the responses in Tables 2 and 4

\begin{tabular}{|c|c|c|c|c|}
\hline Response & Model & $p$-value & $\mathbf{R}^{2}$ & Std. Dev. \\
\hline Total HPLC phenols (mg/kg tyrosol) & $1038.4-34.5 \mathrm{D}-46.0 \mathrm{~T}+1.11 \mathrm{~T}^{2}$ & $<0.0001$ & 0.939 & 47.7 \\
\hline $\begin{array}{l}\text { Total Folin phenols (mg/kg caffeic } \\
\text { acid) }\end{array}$ & $948.1-37.0 \mathrm{D}-37.0 \mathrm{~T}+0.97 \mathrm{~T}^{2}$ & $<0.0001$ & 0.915 & 60.9 \\
\hline DPPH $(\mu \mathrm{mol} / \mathrm{kg})$ & $2439.1-242.3 \mathrm{D}-42.8 \mathrm{~T}+1.97 \mathrm{~T}^{2}$ & $<0.0001$ & 0.939 & 175.2 \\
\hline Total LOX volatiles pathway (mg/kg) & $12.49+0.76 \mathrm{D}-0.24 \mathrm{~T}$ & $<0.0001$ & 0.859 & 0.85 \\
\hline \multicolumn{5}{|l|}{ Phenol compounds (mg/kg) } \\
\hline Hydroxytyrosol & $\begin{array}{l}62.66-13.6 \mathrm{D}-0.71 \mathrm{~T}-0.43 \mathrm{t}+0.13 \mathrm{D} \mathrm{T}+ \\
0.027 \mathrm{Dt}+0.74 \mathrm{D}^{2}+0.002 \mathrm{t}^{2}\end{array}$ & 0.0002 & 0.975 & 0.31 \\
\hline Tyrosol & 1.49 & & & 0.22 \\
\hline Vainillin & 1.52 & & & 0.32 \\
\hline$p$-coumaric acid & $-6.27+1.31 \mathrm{D}+0.25 \mathrm{~T}+0.019 \mathrm{t}-0.045 \mathrm{D} \mathrm{T}$ & 0.0008 & 0.913 & 0.19 \\
\hline trans-ferulic acid & $-1.08+0.12 \mathrm{~T}-0.067 \mathrm{t}+0.004 \mathrm{Tt}$ & $<0.0001$ & 0.942 & 0.81 \\
\hline 3,4-DHPEA-EDA & $380.4-20.9 \mathrm{D}-14.7 \mathrm{~T}+0.41 \mathrm{~T}^{2}$ & $<0.0001$ & 0.904 & 28.4 \\
\hline 3,4-DHPEA-EA & $160.9-11.1 \mathrm{~T}+0.29 \mathrm{~T}^{2}$ & $<0.0001$ & 0.918 & 14.8 \\
\hline$p$-HPEA-EDA & $18.6-0.55 \mathrm{~T}-0.093 \mathrm{t}+0.015 \mathrm{Tt}+0.032 \mathrm{~T}^{2}$ & $<0.0001$ & 0.974 & 3.48 \\
\hline$p$-HPEA-EA & $18.9+11.0 \mathrm{D}-4.62 \mathrm{~T}+0.94 \mathrm{t}-0.13 \mathrm{Dt}+0.098 \mathrm{~T}^{2}$ & $<0.0001$ & 0.961 & 2.99 \\
\hline Pinoresinol & $\begin{array}{l}142.9-36.6 \mathrm{D}+0.27 \mathrm{~T}+0.057 \mathrm{t}+0.52 \mathrm{D} \mathrm{T}+ \\
0.24 \mathrm{Dt}-0.058 \mathrm{Tt}\end{array}$ & 0.0057 & 0.914 & 5.34 \\
\hline Luteolin & 3.30 & & & 1.10 \\
\hline Apigenin & $3.73-0.89 \mathrm{D}+0.11 \mathrm{~T}+0.019 \mathrm{t}$ & $<0.0001$ & 0.922 & 0.32 \\
\hline \multicolumn{5}{|l|}{ Volatile compounds (mglkg) } \\
\hline \multicolumn{5}{|l|}{ LOX pathway } \\
\hline Hexanal & $1.12-0.016 \mathrm{~T}+0.001 \mathrm{t}$ & $<0.0001$ & 0.891 & 0.047 \\
\hline Hexan-1-ol & $0.480+0.049 \mathrm{D}-0.006 \mathrm{~T}+0.0005 \mathrm{t}$ & $<0.0001$ & 0.922 & 0.019 \\
\hline trans-2-hexenal & $-0.124+1.81 \mathrm{D}+0.082 \mathrm{~T}-0.049 \mathrm{D} \mathrm{T}$ & $<0.0001$ & 0.901 & 0.57 \\
\hline trans-2-hexen-1-ol & $\begin{array}{l}-2.95+0.67 \mathrm{D}+0.087 \mathrm{~T}+0.012 \mathrm{t}-0.018 \mathrm{D} \mathrm{T}- \\
0.002 \mathrm{D} \mathrm{t}\end{array}$ & 0.0002 & 0.926 & 0.045 \\
\hline cis-3-hexen-1-ol & $3.37-0.82 \mathrm{D}-0.016 \mathrm{~T}+0.002 \mathrm{t}+0.080 \mathrm{D}^{2}$ & $<0.0001$ & 0.915 & 0.048 \\
\hline cis-3-hexenyl acetate & $\begin{array}{l}0.094+0.45 \mathrm{D}-0.10 \mathrm{~T}+0.041 \mathrm{t}-0.008 \mathrm{D} \mathrm{t}+ \\
0.002 \mathrm{~T}^{2}\end{array}$ & 0.0006 & 0.906 & 0.037 \\
\hline 1-penten-3-ol & $0.376-0.019 \mathrm{D}-0.002 \mathrm{~T}$ & $<0.0001$ & 0.856 & 0.009 \\
\hline 1-penten-3-one & $0.890-0.039 \mathrm{D}-0.001 \mathrm{t}$ & $<0.0001$ & 0.842 & 0.017 \\
\hline cis-2-penten-1-ol & $0.476-0.008 \mathrm{D}+0.001 \mathrm{t}$ & $<0.0001$ & 0.906 & 0.007 \\
\hline$\frac{1}{\sqrt{\text { trans-2-Pentenal }+0.05}}$ & $-13.4+1.04 \mathrm{~T}-0.015 \mathrm{~T}^{2}$ & $<0.0001$ & 0.999 & 0.011 \\
\hline \multicolumn{5}{|l|}{ Sugar fermentation } \\
\hline Ethanol & $-15.7+5.10 \mathrm{D}+0.58 \mathrm{~T}-0.013 \mathrm{t}-0.13 \mathrm{D} \mathrm{T}$ & 0.0003 & 0.908 & 0.36 \\
\hline Acetic acid & 0.47 & & & 0.042 \\
\hline \multicolumn{5}{|l|}{ Other compounds } \\
\hline Octane & $0.239+0.095 \mathrm{D}+0.009 \mathrm{~T}+0.010 \mathrm{t}-0.001 \mathrm{Dt}$ & 0.0001 & 0.904 & 0.029 \\
\hline Pentan-3-one & $-0.134+0.10 \mathrm{D}+0.015 \mathrm{~T}-0.003 \mathrm{D} \mathrm{T}$ & 0.0004 & 0.885 & 0.011 \\
\hline Octanal & $4.45-1.48 \mathrm{D}+0.003 \mathrm{t}+0.150 \mathrm{D}^{2}$ & $<0.0001$ & 0.904 & 0.064 \\
\hline Nonanal & $\begin{array}{l}11.6-1.82 \mathrm{D}-0.22 \mathrm{~T}-0.021 \mathrm{t}+0.001 \mathrm{Tt}+ \\
0.18 \mathrm{D}^{2}+0.003 \mathrm{~T}^{2}\end{array}$ & $<0.0001$ & 0.979 & 0.067 \\
\hline
\end{tabular}

$\mathrm{D}$ is the hole diameter of the hammer-crusher $(\mathrm{mm}), \mathrm{T}$ is the malaxation temperature $\left({ }^{\circ} \mathrm{C}\right), \mathrm{t}$ is the malaxation time (min) $\mathrm{R}^{2}$ is the coefficient of determination, Std. Dev. (SD) is the standard deviation 


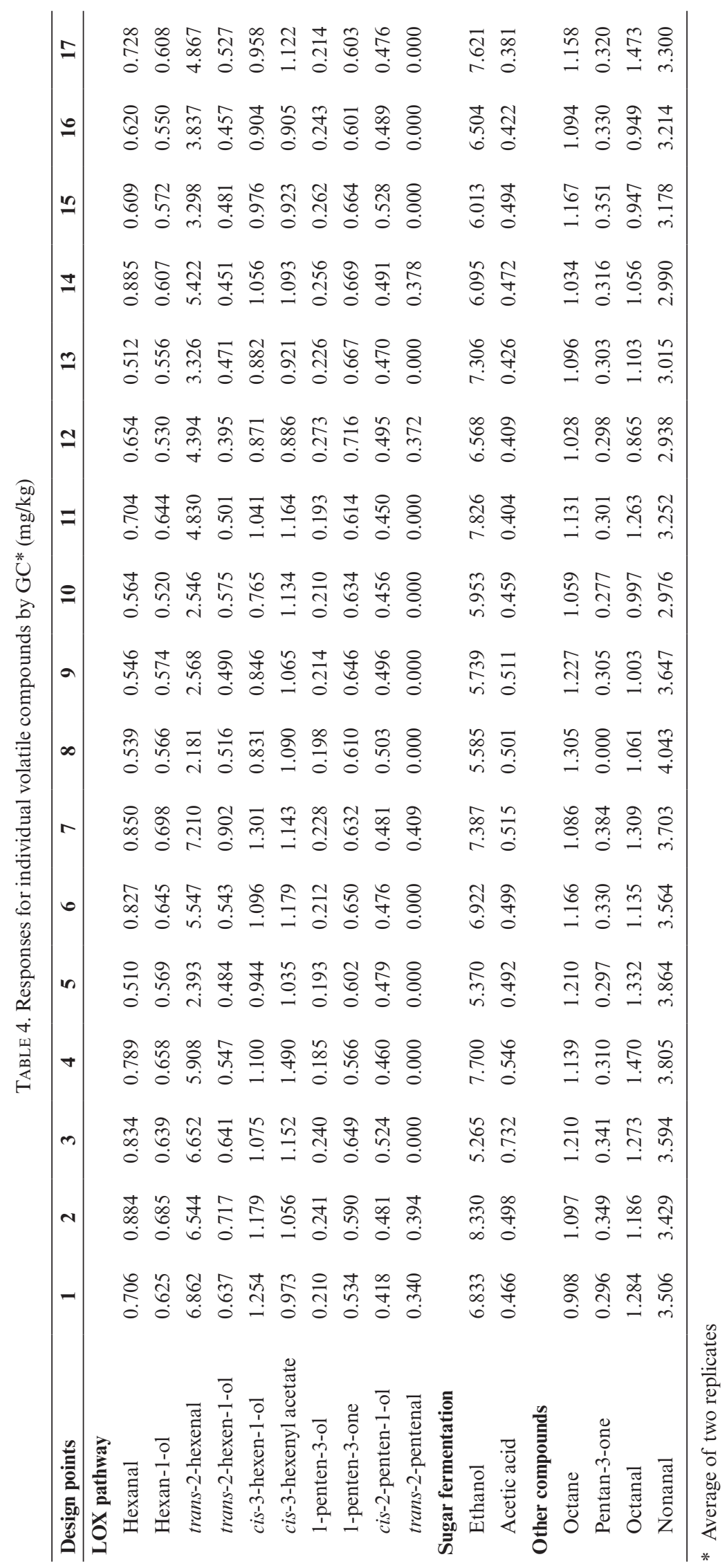


not eliminated from the models, although they were not statistically significant. As can be seen in Tables 1 and 2, all oils meet the condition of being healthy because all of them contain more than $250 \mathrm{mg} / \mathrm{kg}$ of Hydroxytyrosol and its derivatives, according to the Commission Regulation (EU) No 432/2012.

Figure 1 shows the model surface obtained for the total HPLC phenol response; for total Folin phenols (total phenols determined with the Folin-Ciocalteau method), the surface is similar, as can be deduced from the model equation in Table 3 . According to the models, the temperature during malaxation has a major influence on the presence of phenolic compounds, which increase as temperature increases. On the contrary, the phenolic compounds decrease as the diameter of the crusher hole increases, but this has less influence. Similar results were reported by other authors studying malaxation and milling separately (Vekiari and Koutsaftakis, 2002; Ranalli et al., 2003). However, Ben Brahim et al. (2015), using Response Surface Methodology (RSM), indicated that the malaxation time does not significantly affect the phenol content.

Figure 2 shows the relationship between phenolic compound content and the antioxidant potential DPPH, both for total HPLC phenols and total Folin phenols. A very good correlation was observed in it, as is also apparent from the models in Table 3. On the other hand, from Figure 2 and Table 3 a very good correlation between both methods of quantifying total phenolic compounds in the oils is deduced, although the Folin-Ciocalteau method overestimated the content regarding HPLC.

Table 3 shows the proposed models in terms of actual factors for individual phenols; each phenol had a different model, but after examining the response surfaces, small differences were observed

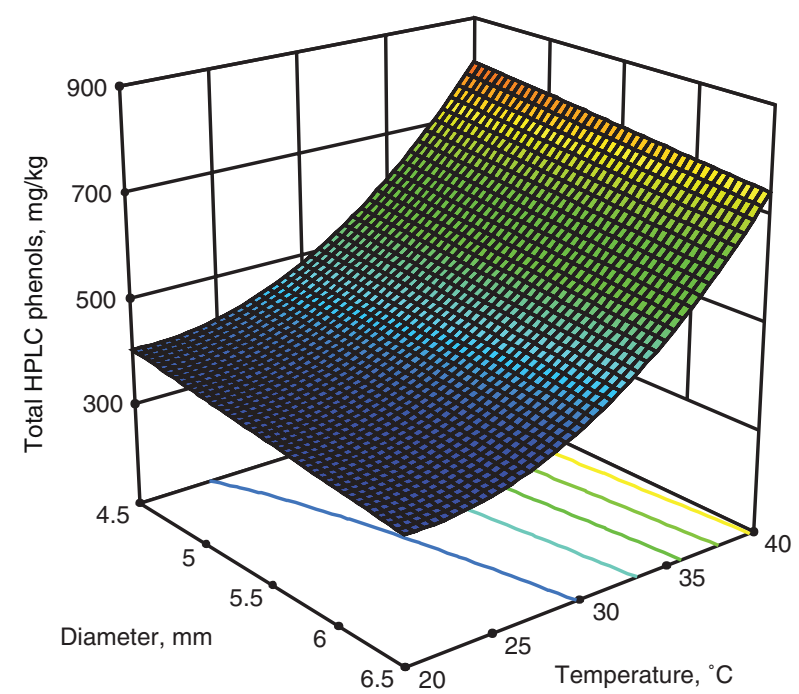

Figure 1. Effects of temperature and hole diameter of the hammer-crusher on total HPLC phenol content among them. The secoiridoid derivative class (3,4-DHPEA-EDA， 3,4-DHPEA-EA， $p$-HPEAEDA and $p$-HPEA-EA) was clearly predominant and all of them increased with temperature. The results are similar to those obtained by other authors (Fregapane and Salvador, 2013; Gómez-Rico et al., 2009; Kalua et al., 2006). In agreement with other papers (Rodis et al., 2002), this increase can be attributed to the increased partition coefficient between the oil and water phases, which causes an increase in the solubility of these compounds in the oil phase.

The malaxation time had a positive influence on secoiridoid derivatives from ligstroside ( $p$-HPEAEDA and $p$-HPEA-EA), but did not show a significant influence on secoiridoid derivatives from oleuropein (3,4-DHPEA-EDA and 3,4-DHPEA-EA). This is in contradiction to Ranalli et al. (2003), who observed a reduction in these secoiridoid derivatives with the time of malaxation, and attributed it to an increase in the oxidative reactions catalyzed by the activity of oxidoreductase enzymes present in the olive fruit such as peroxidase and polyphenoloxidase, due to the fact that olive paste was exposed to air longer when the malaxation time increased. In our case, the positive influence of malaxation time may be due to the increased activity of the $\beta$-glucosidase enzyme that hydrolyzed ligstroside and oleuropein, and the greater phenol content of the Picual variety. Figure 3 shows the response surface for the influence of the temperature and time on oleocanthal ( $p$-HPEA-EDA) content, and of temperature and diameter on oleacein (3,4-DHPEA-EDA) content. For these models, factors that are not considered are not significant.

Different behaviors are also observed in other compounds; for example, pinoresinol decreased when temperature increased with a malaxation time longer than 60 minutes; and luteolin was unaltered. In addition, as seen in Table 3, some models present interaction among the factors; for example, diameter-time in alcohols (hydroxytyrosol and tyrosol) and ligstroside aglycone ( $p$-HPEA-EA), or

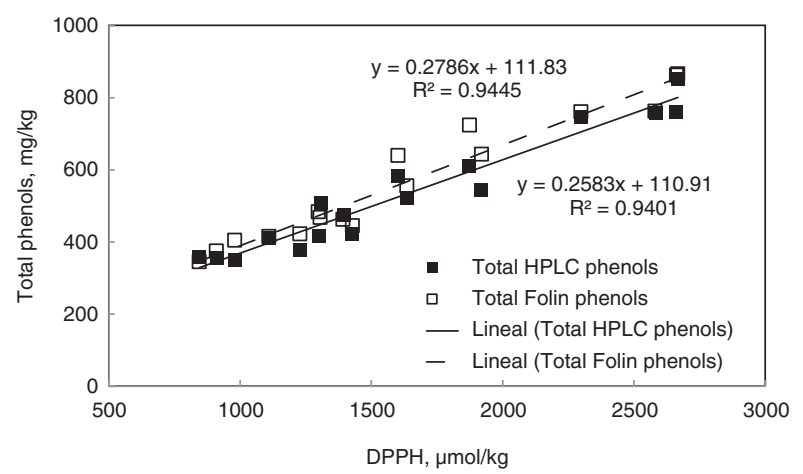

FIGURE 2. Relationship between phenolic compound content and antioxidant potential 

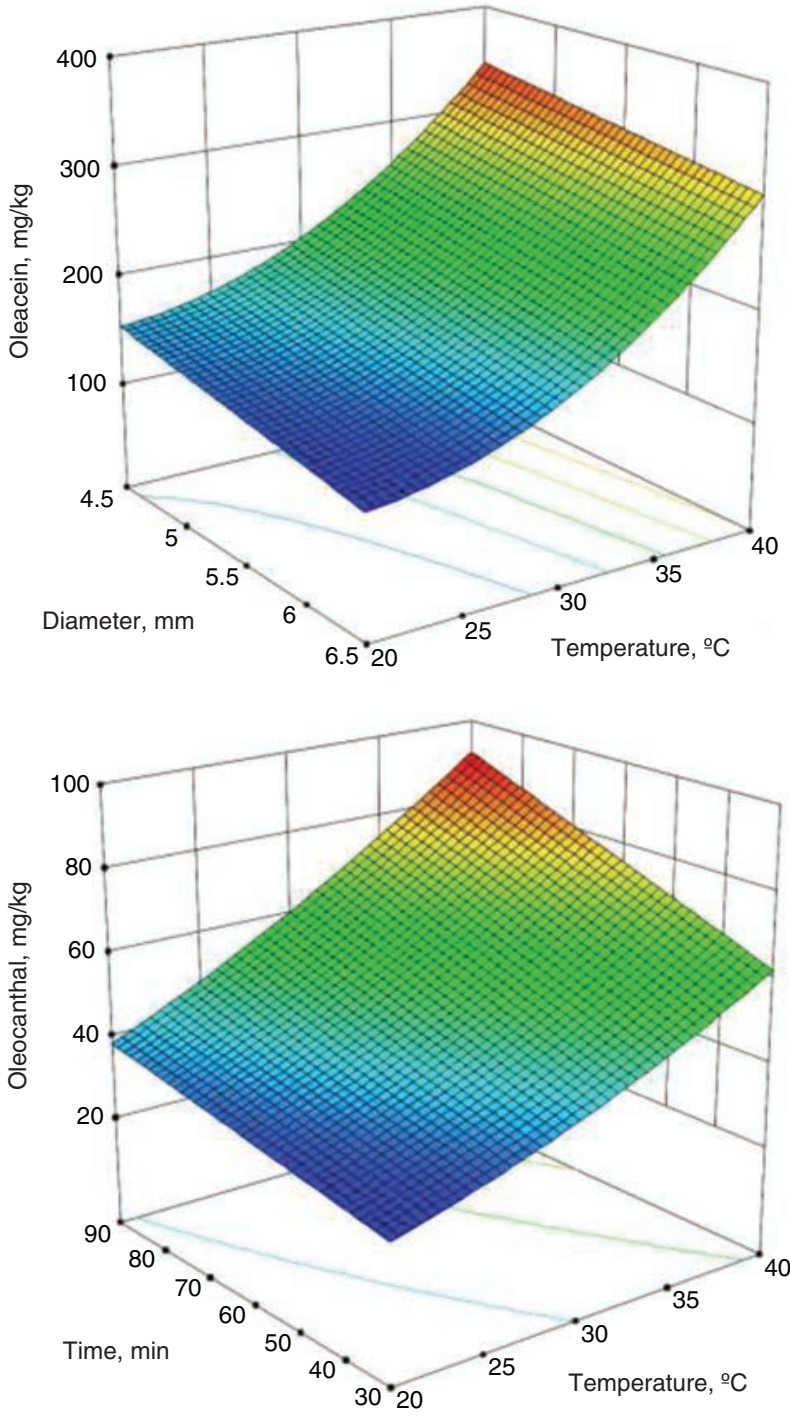

FIGURE 3. Response surfaces for oleacein and oleocanthal content

diameter-time and temperature-time in pinoresinol. Finally, an interaction was observed between temperature and time in oleocanthal ( $p$-HPEA-EDA), in agreement with De Torres et al. (2016).

\subsection{Effect of technological factors on volatile compounds}

Table 4 shows the volatile compound contents grouped according to the most probable precursor molecule and Table 3 shows the models. Only 16, of the 39 analytical standards used were identified in the samples because some analytical standards corresponded to compounds present in olive oils with defects, which are unwanted in extra virgin olive oils. Trans-2-hexenal was clearly predominant. The volatiles arising from the lipoxygenase (LOX)

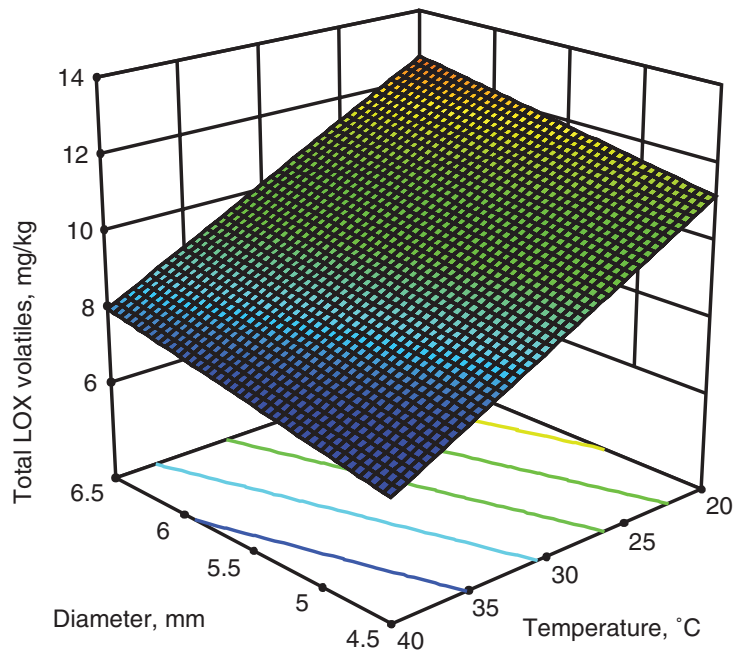

FigurE 4. Effects of temperature and hole diameter on total LOX volatile content

cascade (Angerosa et al., 2004; Kalua et al., 2007) decreased with temperature, but increased with the crusher hole diameter. The malaxation time was not significant. Figure 4 shows the response surface for the influence of diameter and malaxation temperature on total LOX volatile contents. The influence of temperature was observed to be much greater than that of diameter. When temperature was increased from $20{ }^{\circ} \mathrm{C}$ to $40{ }^{\circ} \mathrm{C}$, the content of trans-2-hexenal was reduced by $62 \%$, while the content of 1 -penten3 -ol only fell by $16 \%$. The total volatile compounds decreased by $36 \%$, in agreement with many research papers (Fregapane and Salvador, 2013; Gómez-Rico et al., 2009; Angerosa and Basti, 2001; Ranalli et al., 2001), as a result of the inactivation of hydroxidelyase enzymes (Salas and Sánchez, 1999).

For most of the studied volatiles, a positive dependence was observed with malaxation time, except for 1-penten-3-one, for which one slight decrease was observed. Overall, the total volatile compounds were not significantly affected by the duration of the malaxation.

Finally, some of them increased with the diameter crusher holes: trans-2-hexenal, cis-3-hexenol, hexanol and trans-2-hexenol; while others decreased: 1-penten-3-ol, 1-penten-3-one and cis-2-pentenol. The end result would focus on an increase in total volatile compounds due to the importance of the trans-2-hexenal and cis-3-hexenol. In both cases, the maximum concentration corresponded to a diameter of $6.5 \mathrm{~mm}$ and a temperature of $20^{\circ} \mathrm{C}$.

\subsection{Optimal operating conditions}

In order to achieve the optimal conditions of a balanced EVOO, we aimed to maximize the content in total HPLC phenols and total LOX volatiles 
10 A.M. Vidal, S. Alcalá, M.T. Ocaña, A. De Torres, F. Espínola and M. Moya

TABLE 5. Optimal conditions for the maximum of the main responses and prediction for some usual operating conditions

\begin{tabular}{|c|c|c|c|c|}
\hline \multicolumn{5}{|l|}{ Individual response } \\
\hline & Maximum value & $\begin{array}{l}\text { Diameter } \\
(\mathbf{m m})\end{array}$ & $\begin{array}{c}\text { Temperature } \\
\left({ }^{\circ} \mathrm{C}\right)\end{array}$ & $\begin{array}{l}\text { Time } \\
(\min )\end{array}$ \\
\hline $\begin{array}{l}\text { Total HPLC phenols } \\
\text { (mg/kg tyrosol) }\end{array}$ & 813.5 & 4.50 & 40.00 & -- \\
\hline $\mathrm{DPPH}(\mu \mathrm{mol} / \mathrm{kg})$ & 2795 & 4.50 & 40.00 & -- \\
\hline Total LOX volatiles (mg/kg) & 12.71 & 6.50 & 20.00 & -- \\
\hline \multicolumn{5}{|l|}{ Responses prediction } \\
\hline $\begin{array}{c}\text { Diameter } \\
(\mathrm{mm})\end{array}$ & $\begin{array}{c}\text { Temperature } \\
\left({ }^{\circ} \mathbf{C}\right)\end{array}$ & $\begin{array}{c}\text { Total HPLC phenols } \\
\text { (mg/kg tyrosol) }\end{array}$ & $\begin{array}{l}\text { Total LOX volatiles } \\
\text { (mg/kg) }\end{array}$ & $\begin{array}{c}\text { DPPH } \\
(\mu \mathrm{mol} / \mathrm{kg})\end{array}$ \\
\hline 4.5 & 20 & 406 & 11.2 & 1282 \\
\hline 4.5 & 25 & 425 & 10.0 & 1512 \\
\hline 5.5 & 20 & 372 & 12.0 & 1040 \\
\hline 5.5 & 25 & 391 & 10.8 & 1270 \\
\hline 5.5 & 30 & 465 & 9.6 & 1599 \\
\hline 6.5 & 20 & 337 & 12.7 & 798 \\
\hline 6.5 & 25 & 356 & 11.5 & 1028 \\
\hline 6.5 & 30 & 430 & 10.4 & 1357 \\
\hline 6.5 & 40 & 745 & 8.0 & 2310 \\
\hline
\end{tabular}

and, by extension, the antioxidant activity given its direct dependence with the content of total phenolic compounds (Figure 2). Table 5 shows the optimal values obtained from the derived mathematical models using the Design-Expert software. It can be observed that the optimal conditions are at the contour limits. As can be determined from the models in Table 3, and is seen in Figure 2 and Table 5, the antioxidant activity is closely linked to the total phenol content in such a way that as these were increased the antioxidant activity also increased. In contrast, the variation in total LOX volatiles was completely opposite to that of total phenols, according to the findings of Gómez-Rico et al. (2009) and InarejosGarcía et al. (2011).

Therefore, obtaining balanced olive oils only depends on what is considered a balanced oil and on the operating conditions that are set to obtain the desired content in its different components. In Table 5, the total phenol content, total LOX volatiles and antioxidant activity for different operating conditions were calculated using the models in Table 3 . In order to obtain an extra virgin olive oil which is balanced and of high quality from the Picual variety, it should be elaborated with a malaxation temperature between 20 and $25^{\circ} \mathrm{C}$ and preferably with a hammer-crusher hole diameter of $6.5 \mathrm{~mm}$. Thus, for a hammer-crusher hole diameter of $6.5 \mathrm{~mm} 337$ and $356 \mathrm{mg} / \mathrm{kg}$ total HPLC phenols were obtained for malaxation temperatures of 20 and $25^{\circ} \mathrm{C}$, respectively and, likewise, 12.7 and $11.5 \mathrm{mg} / \mathrm{kg}$ total LOX volatiles. These oils will be fragrant, healthy and, if they do not have defects, of high quality.
When the malaxation temperature is increased healthier but less fragrant oils were obtained and, on the contrary, less healthy but more fragrant oils were obtained at lower temperatures.

\section{CONCLUSIONS}

Temperature is the factor that has the major influence on the phenolic compounds and antioxidant activity; both of them increased as temperature increased. A good correlation between antioxidant activity and phenolic compounds was observed.

Temperature also has the major influence on the volatile compound content, thus when temperature increased from 20 to $40^{\circ} \mathrm{C}$, total volatiles decreased by $36 \%$. The total volatile compounds increased with the hammer-crusher hole diameter.

In order to obtain an extra virgin olive oil which is balanced and of high quality from the Picual variety, the elaboration should be carried out with malaxation temperature between 20 and $25^{\circ} \mathrm{C}$ and preferably with a hammer-crusher hole diameter of $6.5 \mathrm{~mm}$. Thus, for a hole diameter of $6.5 \mathrm{~mm} 337$ and $356 \mathrm{mg}$ / $\mathrm{kg}$ total HPLC phenols were obtained for malaxation temperatures of 20 and $25^{\circ} \mathrm{C}$, respectively and, likewise, 12.7 and $11.5 \mathrm{mg} / \mathrm{kg}$ total LOX volatiles. These oils will be fragrant and nutritionally healthy.

\section{ACKNOWLEDGMENT}

This work is part of the Research Project of Excellence P11-AGR-7726. We wish to thank the Department of Economy, Innovation and Science 
of the Andalusian Regional Government and the Spanish Ministry of Science and Innovation for the financial help provided.

\section{REFERENCES}

Angerosa F, Basti C. 2001. Olive oil volatile compounds from the lipoxygenase pathway in relation to fruit ripeness. Ital. J. Food Sci. 13, 421-428.

Angerosa F, Mostallino R, Basti C, Vito R. 2000. Virgin olive oil odour notes: their relationships with volatile compounds from the lipoxygenase pathway and secoiridoid compounds. Food Chem. 68, 283-287. https://doi.org/10.1016/ S0308-8146(99)00189-2

Angerosa F, Servili M, Selvaggini R, Taticchi A, Esposto S, Montedoro G. 2004. Volatile compounds in virgin olive oil: occurrence and their relationship with the quality. J. Chromatogr. A 1054, 17-31. https://doi.org/10.1016/j. chroma.2004.07.093

Beauchamp GK, Keast RSJ, Morel D, Lin J, Pika J, Han Q, Lee CH, Smith AB, Breslin PAS. 2005. Phytochemistry: Ibuprofen-like activity in extra-virgin olive oil. Nature $\mathbf{4 3 7}$, 45-46. https://doi.org/10.1038/437045a

Ben Brahim S, Marrakchi F, Gargouri B, Bouaziz M. 2015. Optimization of malaxing conditions using $\mathrm{CaCO}_{3}$ as a coadjuvant: A method to increase yield and quality of extra virgin olive oil cv. Chemlali. LWT-Food Sci. Technol. 63, 243-252. https://doi.org/10.1016/j.lwt.2015.03.013

Box GEP, Hunter JS, Hunter WG. 2005. Statistics for Experimenters: Design, Innovation, and Discovery, 2nd Edition. John Wiley \& Sons Inc., New Jersey, USA.

Cicerale S, Lucas LJ, Keast RSJ. 2012. Antimicrobial, antioxidant and anti-inflammatory phenolic activities in extra virgin olive oil. Curr. Opin. Biotechnol. 23, 129-135. https:// doi.org/10.1016/j.copbio.2011.09.006

Clodoveo ML, Hbaieb RH, Kotti F, Mugnozza GS, Gargouri M. 2014. Mechanical Strategies to Increase Nutritional and Sensory Quality of Virgin Olive Oil by Modulating the Endogenous Enzyme Activities. Compr. Rev. Food Sci. Food Saf. 13, 135-154. https://doi.org/10.1111/1541-4337.12054

De Torres A, Espínola F, Moya M, Castro E. 2016. Composition of secoiridoid derivatives from Picual virgin olive oil using response surface methodology with regard to malaxation conditions, fruit ripening, and irrigation management. Eur. Food Res. Technol. 242, 1709-1718. https://doi.org/10.1007/ s00217-016-2670-8

Espínola F, Moya M, Fernández DG, Castro E. 2009. Improved extraction of virgin olive oil using calcium carbonate as coadjuvant extractant. J. Food Eng. 92, 112-118. https:// doi.org/10.1016/j.jfoodeng.2008.10.038

Espínola F, Moya M, Fernández DG, Castro E. 2011. Modelling of virgin olive oil extraction using response surface methodology. Int. J. Food Sci. Technol. 46, 2576-2583. https:// doi.org/10.1111/j.1365-2621.2011.02786.x

Franco MN, Galeano-Díaz T, Sánchez J, De Miguel C, MartínVertedor D. 2014. Antioxidant capacity of the phenolic fraction and its effect on the oxidative stability of olive oil varieties grown in the southwest of Spain. Grasas Aceites 65, e004. https://doi.org/10.3989/gya.051513

Fregapane G, Salvador MD. 2013. Production of superior quality extra virgin olive oil modulating the content and profile of its minor components. Food Res. Int. 54, 1907-1914. https://doi.org/10.1016/j.foodres.2013.04.022

Gómez-Rico A, Inarejos-García AM, Salvador MD, Fregapane G. 2009. Effect of malaxation conditions on phenol and volatile profiles in olive paste and the corresponding virgin olive oils (Olea europaea L. Cv. Cornicabra). J. Agric. Food Chem. 57, 3587-3595. https://doi.org/10.1021/jf803505w

Gómez-Rico A, Salvador MD, La Greca M, Fregapane G. 2006. Phenolic and volatile compounds of extra virgin olive oil (Olea europaea L. Cv. Cornicabra) with regard to fruit ripening and irrigation management. J. Agric. Food Chem. 54, 7130-7136. https://doi.org/10.1021/jf060798r
Inarejos-García AM, Fregapane G, Salvador MD. 2011. Effect of crushing on olive paste and virgin olive oil minor components. Eur. Food Res. Technol. 232, 441-451. https://doi. org/10.1007/s00217-010-1406-4

Kalua CM, Allen MS, Bedgood DR, Bishop AG, Prenzler PD, Robards K. 2007. Olive oil volatile compounds, flavour development and quality: A critical review. Food Chem. 100, 273-286. https://doi.org/10.1016/j. foodchem.2005.09.059

Kalua CM, Bedgood DR, Bishop AG, Prenzler PD. 2006. Changes in volatile and phenolic compounds with malaxation time and temperature during virgin olive oil production. J. Agric. Food Chem. 54, 7641-7651. https://doi. org/10.1021/jf061122z

Luna G, Morales MT, Aparicio R. 2006. Characterisation of 39 varietal virgin olive oils by their volatile compositions. Food Chem. 98, 243-252. https://doi.org/10.1016/j. foodchem.2005.05.069

Ranalli A, Contento S, Schiavone C, Simone N. 2001. Malaxing temperature affects volatile and phenol composition as well as other analytical features of virgin olive oil. Eur. J. Lipid Sci. Technol. 103, 228-238. https:// doi.org/10.1002/1438-9312(200104)103:4<228::AIDEJLT228>3.0.CO;2-7

Ranalli A, Pollastri L, Contento S, Iannucci E, Lucera L. 2003. Effect of olive paste kneading process time on the overall quality of virgin olive oil. Eur. J. Lipid Sci. Technol. 105, 57-67. https://doi.org/10.1002/ejlt.200390018

Rodis PS, Karathanos VT, Mantzavinou A. 2002. Partitioning of olive oil antioxidants between oil and water phases. $J$. Agric. Food Chem. 50, 596-601. https://doi.org/10.1021/ jf010864j

Romero N, Saavedra J, Tapia F, Sepúlveda B, Aparicio R. 2016. Influence of agroclimatic parameters on phenolic and volatile compounds of Chilean virgin olive oils and characterization based on geographical origin, cultivar and ripening stage. J. Sci. Food Agric. 96, 583-592. https://doi. org/10.1002/jsfa. 7127

Salas JJ, Sánchez J. 1999. The decrease of virgin olive oil flavor produced by high malaxation temperature is due to inactivation of Hydroperoxide lyase. J. Agric. Food Chem. 47, 809-812. https://doi.org/10.1021/jf981261j

Sanchez J, Salas JJ. 2003. Biogénesis del aroma del aceite de oliva, in Aparicio R, Harwood J. (Eds.) Manual del Aceite de Oliva. AMV Ediciones y Mundi-Prensa, Madrid (Spain), pp. 89-107.

Scotece M, Conde J, Abella V, Lopez V, Pino J, Lago F, Smith AB, Gómez-Reino JJ, Gualillo O. 2015. New drugs from ancient natural foods. Oleocanthal, the natural occurring spicy compound of olive oil: a brief history. Drug Discov. Today 20, 406-410. https://doi.org/10.1016/j. drudis.2014.10.017

Servili M, Selvaggini R, Esposto S, Taticchi A, Montedoro G, Morozzi G. 2004. Health and sensory properties of virgin olive oil hydrophilic phenols: agronomic and technological aspects of production that affect their occurrence in the oil. J. Chromatogr. A 1054, 113-127. https://doi.org/10.1016/j. chroma.2004.08.070

Tripoli E, Giammanco M, Tabacchi G, Di Majo D, Giammanco S, La Guardia M. 2005. The phenolic compounds of olive oil: structure, biological activity and beneficial effects on human health. Nutr. Res. Rev. 18, 98-112. https://doi. org/10.1079/NRR200495

Vázquez-Roncero A, Janer del Valle C, Janer del Valle ML. 1973. Determinación de los polifenoles totales del aceite de oliva. Grasas Aceites 24, 350-357.

Vekiari SA, Koutsaftakis A. 2002. The effect of different processing stages of olive fruit on the extracted olive oil polyphenol content. Grasas Aceites 53, 304-308. https://doi. org/10.3989/gya.2002.v53.i3.321

Zribi A, Gargouri B, Jabeur H, Rebaï A, Abdelhedi R, Bouaziz M. 2013. Enrichment of pan-frying refined oils with olive leaf phenolic-rich extract to extend the usage life. Eur. J. Lipid Sci. Technol. 115, 1443-1453. https://doi.org/10.1002/ ejlt. 201300037 